\title{
加熱による細菌の損傷
}

\author{
澤 井 淳*1 ・五十嵐英夫*2 ・清 水 賢*1 \\ $\left({ }^{* 1}\right.$ 東京農工大学工学部, ${ }^{* 2}$ 東京都立衛生研究所微生物部)
}

\section{Heat-Induced Injury in Bacteria}

\author{
Jun Sawai*1, Hideo IGARAShI*2 and Masaru Shimizu*1 \\ ${ }^{* 1}$ Faculty of Technology, Tokyo University of Agriculture and Technology: \\ 2-24-16 Nakamachi, Koganei, Tokyo 184, Japan)
}

(*2Depertment of Microbiology, Tokyo Metropolitan Research Laboratory of Public Health:

3-24-1 Hyakunincho, Shinjuku-ku, Tokyo 169, Japan)

\section{はじめに}

微生物を殺菌・除菌する技術のうちで最も重要な位置 を占めているのが, 加熱殺菌である. 食品等の殺菌工程 に扔ける殺菌条件は, 存在する微生物の耐熱性によって 決定される。 より信頼性の高い殺菌条件の設定のため, 耐熱性の変動要因の研究がなされてきた。微生物の耐熱 性は種々の諸条件（加熱前歴, 水分など）によって変動 し, このような研究の方向は, さらに微生物の加熱によ る損傷および死滅機構の把握といったことにもつなが る.これまで数多くの研究者によって, 加熱ストレスの 細菌に及ぼす影響が報告されており，もち万ん現在であ 多方面から研究が行われている。しかし, 細菌は熱に よってどのような障害および損傷を受けるのか，またそ れをどのように修復し回復するのか, 加熱致死の一次的 要因は何か，といったことには今だ明確な解答が得られ ていない，本稿では, 細菌の熱損傷に関するこれまでの 知見をまとめ, 概説するとと屯に, 著者らの研究の一部 を紹介する。

\section{損偤細 菌}

それでは, 損傷細菌の定義とはどのようなあのであろ うか. 微生物を増殖可能な上限温度以上の温度にさらす 之, 增殖が停止し死滅が起こる。加熱処理された細菌は, ある種の薬剤に対する感受性が高まったり, 栄養要求性 が厳しくなったりすることは, 古くから知られていた。 特に增殖可能な上限温度からそれほど高くない温度で は, 多かれ少なか細菌は損傷を受けており, 生きてい く環境が不適当な条件では生育しないか，あるいは死滅 するような不安定な状態に陷る27). したがって，損傷細 菌の一つの定義としては,「非選択培地には発育するが,

\footnotetext{
*1 画184 東京都小金井市中町 3-24-16
}

*2 齿169 東京都新宿区百人町 3-24-1
選択培地では発育しない細菌」ということである ${ }^{13)}$.

また, 損傷を受けた細菌は, 損傷が回復したのちに増 殖を開始することが報告されている。したがって，この 増殖の遅れ時間を濁度法等で測定することによっても, 損傷細菌を定義することが可能である ${ }^{48)}$.

これまで, 細菌が熱損傷を受ける部位として, 多くの 報告があり大別すると, (1) タンパク質 (䣼素), (2) 細胞 壁扔よび細胞膜, (3) DNA, (4) RNA およびリボソームの 4 種に分類できる ${ }^{46)}$. 以下, それぞれの部位において, 加 熱によりどのような損傷が引き起こされるのかについて 述べる.

\section{酵素の变性, 失活}

酵素は，様々な生体反応の担い手であり，酵素を含め た蛋白質の種類の総数は, 細菌に扔いて約 3,000 種と言 われている. 細胞内の種々の酵素活性の熱安定性を調べ る研究は古くから行われてきた. ROSENBERG らは, 以下 のような報告を行っている. 細菌の熱死滅が細胞内の蛋 白質の熱失活之同様に一次反応速度式に従い, さらに反 応速度の絶対温度依存性を示すアレニウスプロットから 求められる活性化エネルギーの值が高いことの理由か ら, 細胞内の特定の酵素蛋白質の变性・失活が細胞の生 存性を決定づけているとしている33).

はたして, 細菌中のどの酵素の失活が死滅を支配して いるのだろうか. RoN らは, 最小栄養培地で増殖した大 陽菌に扔いて, 温度上昇に伴う增殖速度の低下は, メ于 オニン合成系の最初の酵素であるホモセリントランスサ クシニラーゼの失活に起因すると報告した。この醳素 は, 他の酵素と比較して熱感受性が高かった。しかし, 44 抢よび $47^{\circ} \mathrm{C}$ で加熱後の細菌を培養するための培地 にメチオニンを添加しても，その影響は認めら饥なかっ た。このことから, 死滅は別の機構によるものと推察さ 机ている ${ }^{31,32) .}$

酸化ストレスに対する防御酵素であるカタラーゼや 
スーパーオキシドジスムターゼなどの種々の酵素の熱感 受性を調べてみると, 酵素によって多少の相違は確かに 認められたが，菌株や菌種によってその結果は異なり， 細菌の熱感受性とこれらの酵素活性との相関は認められ ていない3,5).

次の細胞膜の項においても述べるが，酵素の存在場 所, 存在状態といった側面から, 細胞膜リン脂質の化学 的性状が異なれば，膜に結合している酵素の熱安定性も 変化するのではないかという考え方基にして研究が行 なわれた。膜脂質はそれぞれある温度で相転移を起こす が，膜に結合しているATP 分解酵素 (ATPase) のアレ ニウスプロットにおける変曲点は, 相転移温度の近くに あることが明らかにされた，膜結合蛋白質の熱安定性 は，膜脂質の性状によって大きく左右される場合のある ことが報告された。しかしながら，膜結合 NADH オキ シターゼやフォスファターゼについては, 調べた温度範 囲内では, 活性と膜脂質の性状との相関は認められな かった ${ }^{55)}$ 。少なくとも現状では，どの酵素が加熱による 致死の標的となっているかについてはわかっていない.

\section{細胞膜および細胞壁の損傷}

細菌の細胞を外側から考えた場合，加熱によって細胞 表層に何らかの変化が引き起こされるのだろうか。加熱 された細菌から $\mathrm{K}^{+}, \mathrm{Mg}^{2+}, \mathrm{Ca}^{2+}$ 等の無機イオン, アミ ノ酸, $260 \mathrm{~nm}$ 吸収物質などが放出, 遊離してくること が知られておう ${ }^{34,50)}$, 細菌の細胞膜の損傷が原因と考え られると報告されている。

加熱による形態变化に関する研究も行なわれている。 グラム陰性菌の細胞壁は, 細胞質膜 (内膜), ペプチドグ リカン層, 外膜の 3 層からなり, 内膜とペプチドグリカ ンの間はペリプラズムと呼ばれる。グラム陽性菌は外膜 を持たないが，厚いペプチドリカン層を持っている。de PETRIS は, $75 \sim 100^{\circ} \mathrm{C}$ で加熱したE. coli の外膜に水泡 様構造 (bleb) が形成されることを示した6). KATSUI ら は, bleb は分裂中の細胞の隔壁や極部分に多く形成さ れ，加熱を続けると膜胞 (vesicle) となって遊離するこ とを報告した，さらにこの膜胞は，疎水性物質に対する 透過阻止作用を示すリポ多糖や，親水性低分子物質の透
過孔であるをポーリンなどの外膜成分から形成されてい ることを示した ${ }^{20)}$. また，加熱中，ペリプラズム酵素は 遊出するが，細胞質酵素は漏洩しないことを明らかにし $た^{45)}$.

細菌細胞はその膜機能を正常に働らかすために，環境 温度に応じて膜の流動性を一定に保つ調節機構を有して いる。脂質は温度に依存してゲルー液晶相転移を起こす が，細胞膜は様々な種類の脂質を含むので，ある温度幅 をもって協同的に転移を起こし，またゲル状態と液晶状 態の混在した相分離も起こすことがある ${ }^{42,50)}$. E . coli の 各種脂肪酸要求株を用いた実験などの結果, 細胞膜脂質 が液晶状態を保持している限り，膜と結合している酵素 は活性を維持し，物質の膜透過機能および呼吸機能を発 揮することが明らかにされた ${ }^{55)}$. GRAU は，50ㄷ で加熱 した E. coli の死滅之膜機能について調べているが，生 育不能となった細菌においても，膜機能は健全に保たれ ていることを報告した ${ }^{9)}$. 細胞膜に注目した研究は多い が，結論的には細菌の細胞膜が加熱作用点の一次作用点 であるという直接的な証拠はないものと考えられてい $ろ^{1)}$.

細菌の細胞膜の損傷は，適当な培地で培養することに より修復される．少なくとも回復直後の再増殖時の細菌 は，無傷の細菌之は全く同じ表層構造ではないようであ $ろ^{49)}$.

\section{DNA の損傷と修復}

1950 年代にはいり, 熱が突然変異誘発作用を持ち, 加熱により DNA が不安定な状態になることが，E. coli や B. subtilis の突然变異株を用いた実験において見出 された。この突然変異の頻度の上昇は, 加熱により DNA の脱プリン化（アデニン，グアニン）と関連してい ると考えられている11,57)。 また，BRIDGES らは，E. coil を $52^{\circ} \mathrm{C}$ で加熱 (mild heating)すると, 細胞内の DNA が放射線照射の場合と同様に，一本鎖切断が引き起こさ れ低分子化することを初めて報告した ${ }^{21}$ 。またWOODCock らは, E. coli において $52^{\circ} \mathrm{C}, 15$ 分間の加熱により DNA の二本鎖切断も起こることを報告している ${ }^{54)}$ 。

加熱による DNA 鎖切断の機作については，現在二つ



図 1 エンドデオキシリボヌクレアーゼによる加熱された細菌の DNA 鎖切断. 
の機序が考えられている。一つは DNA 分解酵素の作用 によるあのである（図 1). in vitroにおいて, nativeな DNA は, $100^{\circ} \mathrm{C}, 10$ 分間の加熱でも一本鎖切断は起こ らない51)。このことからも加熱に打いて，直接的または 物理的に一本鎖切断が起こるとは考えにくく，細胞内の 条件が加熱によるDNA の切断を左右していると考えら れる。前述したように，加熱により DNA に脱プリン部 位が生じることが知られており，このようなDNAの modification 部位に作用する酵素であるエンドデオキ シリボヌクレアーゼが単離されている。 LJUNGQUIST は, 脱プリン部位と脱ピリジン部位において，特異的に DNA 鎖を切断するエンドデオキシリボヌクレアーゼ (endonuclease IV) をE. coli より単離した ${ }^{21)}$ ）この酵素 はEDTAの存在下で十分に活性を保持し，さらに熱に はかなり安定であり，65ㅇ の加熱でも失活せず，活性を 保持している。このような高温においても活性を保持す るエンドデオキシリボヌクレアーゼは，他にも単離され ている ${ }^{4,22,37)}$. したがって, 脱プリン・脱ピリジンエンド ヌクレアーゼ欠損株 $(\mathrm{xthA})$ では DNA 鎖の切断が少な (

もう一つは DNA 鎖切断の機序としては，酸化防止機 構の障害の結果引き起こされるものである．加熱された 細胞の培地にカタラーゼやピルピン酸などの活性酸素捕 獲剂を添加すると, 著しく生菌数が増加することが報告 されている25,30). また， E. coli の DNA 修復機能欠損株 を加熱した際の DNA 鎖切断は，培地にカタラーゼを添 加することにより激減することが明らかになってい $ろ^{24)}$.

活性酸素による核酸の損傷は，現在多角的に検討され ており，活性酸素による細菌の核酸の損傷およびDNA 鎖切断が報告されている ${ }^{28)}$ ：また，GoMEZ は，加熱に よって引き起こされる DNA 鎖の切断は，好気条件より 屯嫌気条件の方が少ないことを明らかにした ${ }^{8)}$ ここのよ うなことから，酸化ストレスもまたDNA 切断の機序と 考えられている.

DNA の損傷は加熱後の細菌を適当な条件下で培養す ることによって修復される，PELLON とGOMEZ は，加熱 による損傷の修復には，アミノ酸を添加してもその影響 は認められないことを報告しており，熱損傷からの回復 には蛋白質合成は直接作用していないことを示唆してい
$3^{29)}$.

\section{RNA とリボソームの損傷}

リボソームは細胞内における蛋白質生合成の場であ り，40〜60\%の RNAと60４0\%の蛋白質から成る RNA・蛋白質複合体である. 沈降係数は $70 \mathrm{~S}$ であり, $30 \mathrm{~S}$ と $50 \mathrm{~S}$ のサブユニットから成り立っている. リボ ソーム粒子の間の会合は，存在する $\mathrm{Mg}^{2+}$ イオン濃度に 依存している.

SoGIN ら ${ }^{43)}$ は, S. aureus を $55^{\circ} \mathrm{C}$ で 15 分間加熱する と, $7.5 \% \mathrm{NaCl}$ を含んだ寒天培地で増殖が不可能になる が，一定時間後に回復する。この回復プロセスには蛋白 質合成は含まれず，核酸合成が活発に起こることを示し ている.さらに，このような熱炕理による核酸の損傷部 位はRNAとrRNAであった。加熱により沈降係数 $70 \mathrm{~S}$ であるリボソームが $30 \mathrm{~S}$ と $50 \mathrm{~S}$ のサブユニット に分離し, rRNA の場合, 加熱により $260 \mathrm{~nm}$ の吸収物 質が消滅することを明らかにした。ToMLINS ら ${ }^{44)} は ， S$. typhimurium を用いて, さらに詳細な下記のような結果 を報告している．加熱により分解した $50 \mathrm{~S}$ リボソーム サブユニットは，さらに $47 \mathrm{~S}$ に沈降係数を持つ粒子に 分解した． $30 \mathrm{~S}$ のサブユニットは，完全に消滅し，小さ い沈降係数を持つ粒子に分解した（図 2). また rRNA については, 16 S RNA が 30 分間の加熱で消滅し, 23


解は細胞内 $\mathrm{Mg}^{2+}$ が漏洩して, その濃度が低下すること によりリボソーム粒子が不安定になること, rRNAの分 解は DNA 同様リボヌクレアーゼの活性化がその要因で あると報告している.

加熱処理した細菌を適当な条件で培養することによ り，リボソームおよび rRNA は修復される。 その修復段 階においてはリボソームサブユニットの再生が律速のよ うであり，蛋白質合成は含まれないことは注目される77.

しかしながら，rRNAの分解は細菌をほかのストレ ス，あるいは飢餓条件にさらしたときにあ起こることが 知られている19)。したがってリボソームおよび rRNAの 分解は，細菌にとっては致死的なものではなく，損傷之 いうよりむむしろヌクレオチドの蓄積や，エネルギー源 として利用されるなどの合目性があるのではないかとも 考えられている ${ }^{26)}$.
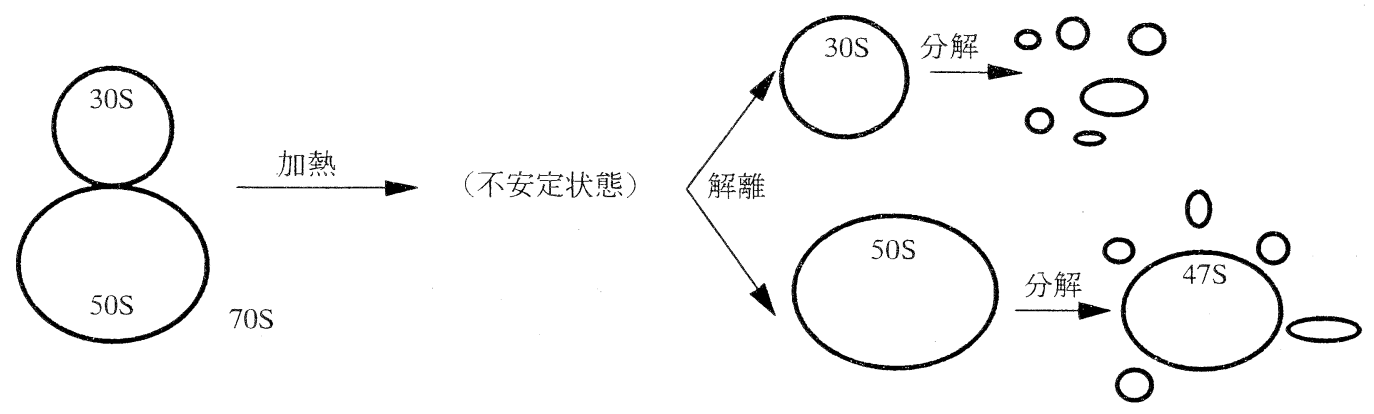

図 2 リボソーム粒子の加熱による分解. 


\section{加熱による損甥機序について}

上述したように，これまで加熱による損傷について多 くの研究がなされている. また近年, 熱ショック応答の 研究が盛んに行われている ${ }^{56}$. 細菌に熱ショック（温度 のシフトアップ）を与えると，熱ショック蛋白質 (HSP) と呼ばれる一群の蛋白質が一過的に合成される，この熱 ショック応答は細菌から高等動物細胞に至るまで普遍的 に存在する現象である。HSP は高温ストレスにおける 細胞防御のグローバルコントロールとして, 耐熱性の上 輩, 損傷の修復あるいは蛋白質の折畳みや会合を助ける シャペロン分子など様々な役割を果たすことが報告され ている50)。それだけでなく, 熱ショック応答の研究から 解明された遺伝子発現の機構に関する研究成果は決して 少なくない。しかしながら，各部位に㧍ける個々の損傷 および熱ショック応答は把握されつつあるものの, 加熱 による損傷・死滅の全容は，今だ明らかになっていな い。さらに, 細菌の損傷について検討する場合, 簡単に 損傷部位を検出するような評価方法は確立していない。

著者らは，主に遠赤外線による殺菌について研究を 行っている ${ }^{14 \sim 17)}$. 研究を進めていく上で, 遠赤外線照射 殺菌の殺菌機序を把握する必要性が生じてきた。遠赤外 線は加熱効果を有する電磁波であり, 加熱殺菌とは密接 な関連がある。そこで, 加熱を含めストレスによる細菌 の損傷部位を簡単に評価する方法を検討した。

これまで, 加熱することにより，細菌の抗生剂抢よび 各種阻害剂に対する感受性がより高まることが知られて いる23,47)。そこで著者らは，「加熱などのストレスによっ て生じた損傷細菌は，その損傷部位の近傍に作用機序を 有する抗生剤に対して非損傷細菌よりも感受性が高ま る」という仮説を立てた，つまり，各種抗生剂を含んだ 寒天培地（選別培地）を用いて，ストレスによって生じ た損傷細菌の感受性の変化を比較することにより，損傷 部位の簡便な検索を試みた。以下の抗生剂を損傷部位の 選別剂として用いた。

(1) クロラムフェニコール (CP): 蛋白質合成阻害

(2) リファンピシン (RFP): RNA 合成阻害

(3) ナリジスク酸 (NA): DNA 合成阻害

(4) ペニシリン $\mathrm{G}(\mathrm{PCG})$ : 細胞壁合成阻害

寒天培地中の選別剂の濃度は，ストレスを受けていな い供試細菌 (E. coli) のコロニ一形成数に全く影響を及ぼ さない範囲とした。寒天培地中の選別剂の濃度は図 3 よ り決定した。図 3 の縦軸は, 非選別培地に発育したコロ ニ一数と選別培地に発育したコロニー数の比 $\left(\mathrm{N}_{1} / \mathrm{N}_{10}\right)$ であり，横軸は寒天培地中の PCG 濃度である.PCG 濃 度が $14.8 \mu \mathrm{g} / \mathrm{m} l$ よりも高くなると $\mathrm{N}_{1} / \mathrm{N}_{10}$ は急激に減 少した。 そこで, 寒天培地中の PCGの最高濃度を 14.8 $\mu \mathrm{g} / \mathrm{m} l$ とし, 損傷部位検索に関する検討を行った。スト レスを受けた細菌を，この最大濃度の選別剂を含む選別 培地で培養することにより, 極めて軽度の損傷をあ検出

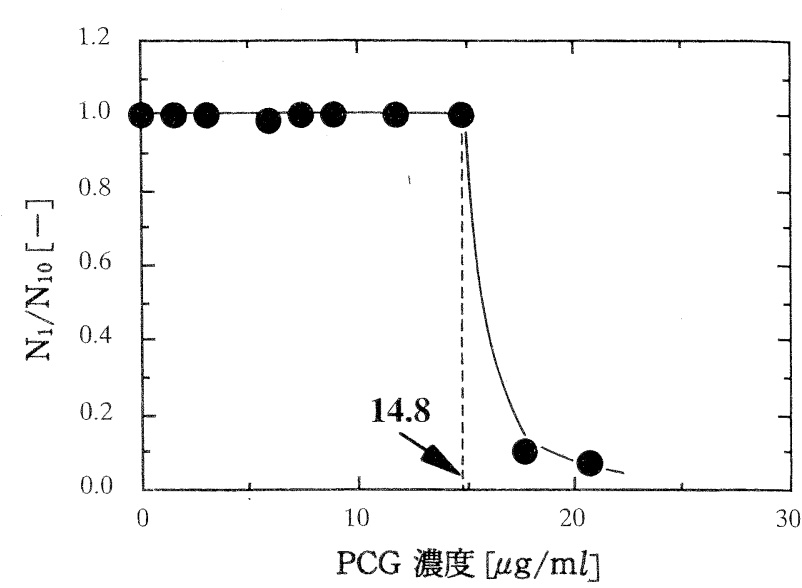

図 3 コロニー形成数に及ぼす寒天培地中の選別剂（ペニ シリン G) 濃度の影響.

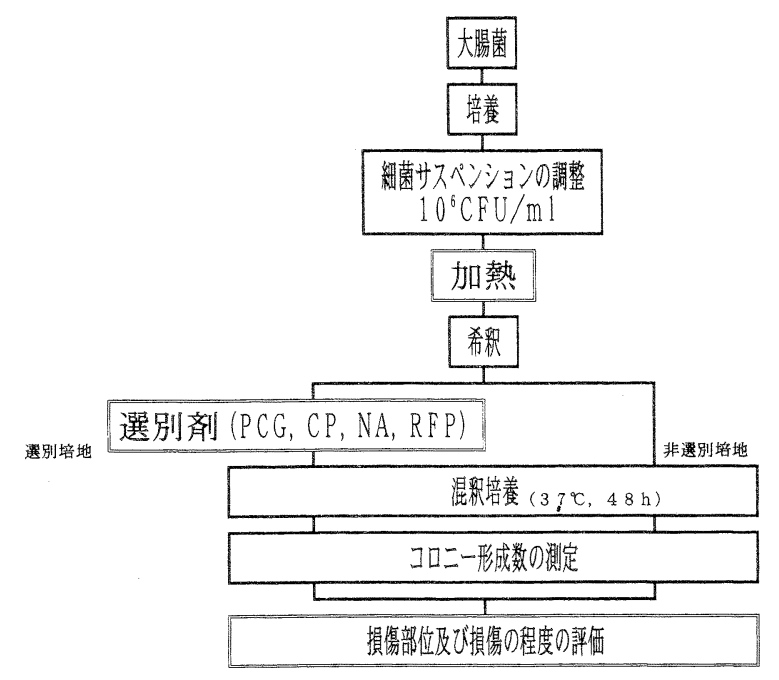

図 4 実験操作手順.

が可能であると考えた。他の抗生剂についても同様な方 法で使用濃度を決定した。

以上のように決定した抗生剤を含む選別培地を用いた 本評価法の妥当性については，紫外線照射殺菌により検 討した。紫外線照射の殺菌機構はよく把握されており， その作用部位は核酸 (DNA, RNA) である。そこで，紫外 線照射した E. coli を本評価方法により選別培地で培養 し，感受性の変化を調べたところ，NA および CP に対 する感受性が高まった。これは，DNA およびリボソー ム中の RNA に損傷が引き起こされていると考えられ, これまでの報告されている損傷部位と一致した。また， その他のストレスとして凍結融解, 酸処理 ${ }^{35,36)}$, アルカ リ処理, また抗菌性セラミックス 38 40)枋どについても本 評価方法により同様な検討を行った。 そして，ストレス により選別剂に対する感受性の变化は異なっていた。 以 上より，本法によりストレスによる細菌の損傷部位の簡 便な検索ができるむのと考えた。

そこで，E. coli の熱損傷について検討した。図4に は, 実験操作の手順を示した。加熱条件は図 5(a) のとお りであり，その条件下で E. coli は図 5(b) のような死滅 


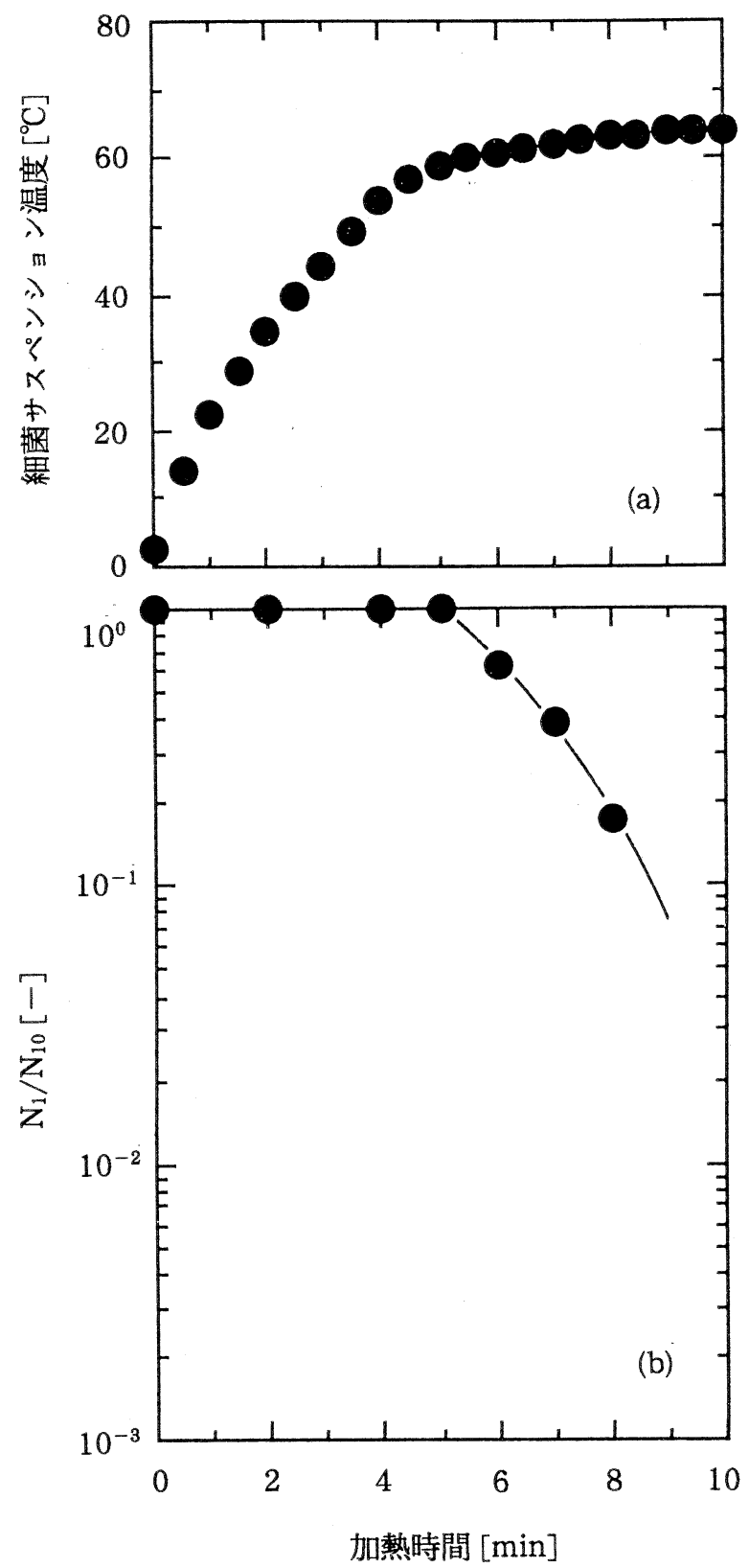

図 5 細菌サスペンションの温度变化 (a) と加熱による殺 菌効果 (b)

曲線を示した。約 $57^{\circ} \mathrm{C}$ 付近から，E. coli の死滅が始ま り，RFP, CP, PCG に対する感受性が高まった。特に RFP に対する感受性の変化が最も大きくなった。図 6 には, 加熱開始 8 分後の E. coli の選別剤に対する感受 性の変化を示した。横軸 $\mathrm{C} / \mathrm{C}_{\mathrm{MAx}}$ は，選別剂最高濃度に 対する供した寒天培地中の選別剤濃度の比である。加熱 温度の上昇に伴い, 生存率は約 $1 / 10$ に減少 $\left(\mathrm{C} / \mathrm{C}_{\mathrm{MAX}}=\right.$ 0) した. RFPに対する感受性の上昇につづいて，次に $\mathrm{CP}$ に対する感受性が著しく上昇し，E。 coli は死滅した. 一方, PCG およびNA に対する感受性の変化は全く認 められなかった。この結果は，加熱により細菌の RNA ポリメラーゼの RNA 合成およびリボソームにおける蛋 白質合成に何らかの障害が起こっていることを示唆して

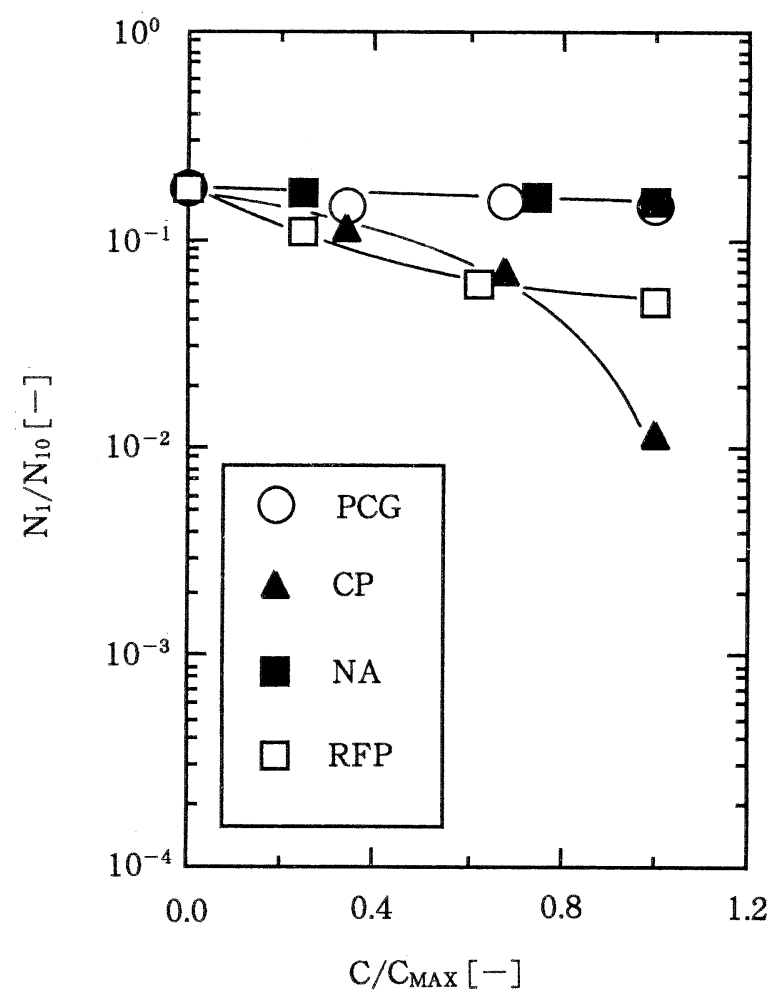

図 6 加熱された E. coli の選別剂に対する感受性の变化 (加熱 8 分後).

いる ${ }^{41)}$. RNA ポリメラーゼは, 熱ショック蛋白質の合成 に極めて重要な役割を果たしている。また，熱ショック によりリボヌクレアーゼが生合成されること ${ }^{12)}$ ，さらに リボソーム自身が熱変化を感知するセンサーとして働い ている可能性のあることが報告されている ${ }^{52)}$. 以上のよ うなことを総合すると，図6に示されるように加熱され た E. coli の 4 種類の選別剂に対する感受性の变化は興 味深いものがあると考えている。

また，本方法による細菌の損傷の評価は，スパイラル プレーティング法, 自動コロニーカウンターなどと組合 わせ，より多種類の選別剂を使用することにより，さら にきめ細かく多くのストレスに対応でき，細菌の損傷部 位の検索が可能であると言える。

おわりに

$\gamma$ 線や紫外線の殺菌機構，特に DNA の損傷・修復に 関しては，今まで多くの研究があり，著しい放射線科学 の発展をもたらした。しかしながら，実際的な立場から はより重要であるはずの熱処理すなわち加熱が，細菌に 対してどのような影響を与えるのかについては，解明に 程遠いというのが現状である，紙面の制限もあり，本稿 ではほとんど触れることができず割愛したが，熱ストレ ス応答および熱ショック蛋白質の研究は, 癌の温度療法 という観点からも注目されており ${ }^{18)}$ ，加熱による細菌の 損傷および死滅機構の研究は, 生物学における最屯基本 的であり，なおかつ応用的な側面を合わせ持った研究 
テーマの一つであるといえよう。今後のこの研究分野の

発展が期待される。

\section{文献}

1) Allwood, M. C. and Russell, A. D.: Mechanisms of thermal injury in nonsporulating bacteria. Adv. Appl. Microbiol., 12, 89-119 (1970).

2) Bridges, B. A., Ashwood-Smith, M. J. and Munson, R. J.: Correlation of bacterial sensitivities to ionizing radiation and mild heating. J. Gen. Microbiol., 58, 115-124 (1969).

3) Bucker, E. R. and Martin, S. E.: Superoxide dismutase activity in thermally stressed Staphylococcus aureus. Appl. Environ. Microbiol., 41, 449-451 (1981).

4) Bueke, Jr., W. F. and Spzizen, J.: Iaolation, characterization, and activation of the magnesium-dependent endodeoxyribonuclease from Bacillus subtilis, Biochemistry, 16, 403-410 (1977).

5) Dallmier, A. W. and Martin, S. E.: Catalase and superoxide dismutase activities after heat injury of Listeria monocytogenes. Appl. Environ. Microbiol., 54, 581582 (1988).

6) de Petris, S.: Ultrastructute of the cell wall of Escherichia coli and chemical nature of its constituent layers. J. Ultrastruct. Res. 19, 45-83 (1967).

7) Flowers, R. S. and Martin, S. E.: Ribosome assembly during recovery of heatinduced Staphylococcus aureus cells. J. Bacteriol., 141, 645-651 (1980).

8) Gomez, R. F. and Shinskey, A. J.: Effect of aeration on mineral medium recovery of heated Salmonella typhimurium. J. Bacteriol., 122, 106-109 (1975).

9) Grau, F.H.: Significance of the inactivation of transfort in thermal death of Escherichia coli. Appl. Environ. Microbiol., 36, 230-236 (1978).

10) Gray, R. J. H., Witter, L. D. and Ordal, Z. J.: Characterization of mild thermal stress in Pueudmonas fluorescens and its repair. Appl. Microbiol., 26, 78-85 (1973).

11) Greer, S. and Zamenhof, S.: Studies on depurination of DNA by heat. J. Mol. Biol., 4, 123-141 (1962).

12) Harder, B. S.: Heat shock induction of ribonucleases in Saccharomyces cerevisiae, FEMS Microbiol. Lett., 17, 23-26 (1983).

13）春田三佐夫：食品検查ニュース，第 25 号，(1988)。

14）橋本 篤, 清水 賢, 五十嵐英夫: 生理的リン酸緩衝溶 液中に浮遊する細菌の殺菌に及ぼす遠赤外線の影響. 化 学工学論文集, 17, 627-633 (1991).

15) Hashimoto, A., Sawai J., Igarashi, H. and Shimizu, M.: Effect of far-infrared irradiation on pasteurization of bacteria suspended in liquid medium below lethal temperature. J. Chem. Eng. Japan, 25, 275-281 (1992).

16) Hashimoto, A., Igarashi, H. and Shimizu, M.: Farinfrared irradiation effect on pasteurization of bacteria on or within wet-solid medium. J. Chem. Eng. Japan, 25, 666-671 (1992).

17) Hashimoto, A., Sawai, J., Igarashi, H. and Shimizu, M.: Irradiation power effect on pasteuriazation below lethal temperature. J. Chem. Eng. Japan, 26, 331-333
(1993).

18）畑山 巧：温熱療法の細胞生物学的基礎と温熱耐性の分 子機構. 最新医学, 49, 76-84 (1994).

19) Kaplan, R. and Apirion, D.: Decay of ribosomal ribonucleic acid in Escherichia coli cells starved for various nutrients. J. Biol. Chem., 250, 3174-3178 (1975).

20) Katsui, M., Tsuchido, T., Hirayama, R., Fujikawa, S., Takano, M. and Shibasaki, I.: Heat-induced blebbing and vesiculation of the outer membrane of Escherichia coli. J. Bacteriol., 151, 1523-1531 (1982).

21) Ljugquist, S.: A new endonuclease from Escherichia coli acting at apurinic sites in DNA. J. Biol. Chem., 252, 2808-2814 (1977).

22) MacCarthy, C. and Nester, E. W.: Heat-activated endonuclease in Bacillus subtilis, J. Bacteriol., 97, 14261430 (1969).

23) Mackey, B. M.: Changes in antibiotic sensitivity and cell surface hydrophobicity in Escherichia coli injured by heating, freesing, drying or ganmma radiation. FEMS. Microbiol. Lett., 20, 395-399 (1983).

24) Mackey, B. M. and Seymour, D. A. The effect of catalase on recovery of heat-injured DNA-repair mutants of Escherichia coli J. Gen. Microbiol., 133, 1601-1610 (1987).

25) Martin, S. E., Flowers, R. S. and Ordal, Z. J.: Catalase: Its effect on microbiol enumeration, Appl. Enviorn. Microbiol., 32, 731-734 (1976).

26）丸山博巳：細菌リボゾームの in vivo 分解之異常亜粒子, 蛋白質 核酸 酵素, 17, 13-20, 92-104 (1972).

27) 森地敏樹：各種理学的処理で生ずる非致死的損傷菌の特 徵之その検出法, 防菌防徽, 17, 541-550 (1989).

28）長野哲雄, 広部雅昭, 活性酸素による核酸の損傷, 蛋白 質 核酸 酵素, 31, 3094-3101 (1988).

29) Pellon, J. R. and Gomez, F.: Repair of thermal damage to Escherichia coli nucleoid. J. Bacteiol., 145, 14561458 (1981).

30) Rayman, M. K., Aris, B. and Derea, B. E.: The effect of compounds which degrade hydrogen peroxide on the enumeration of heat-stressed cells of Salmonella semftenberg, Can. J. Microbiol., 24, 883-885 (1978).

31) Ron, E. Z. and Davis, B. D.: Growth rate of Escherichia coli at elevated temperature: Limitation by methione. J. Bacteriol., 107, 391-396 (1971).

32) Ron, E. Z. and Shani, M.: Growth rate of Escherichia coli at elevated temperature: Reversible inhibition of homoserine trans-succinylase. J. Bacteriol., 107, 397400 (1971).

33) Rosenberg, B., Kemeny, G., Switzer, R. C. and Hamilton, T. C.: Quanitative evidence for protein denaturation as the cause of thermal death. Nature, 232, 471473 (1971).

34) Russell, A. D. and Harries, D.: Some aspects of thermal injury in Escherichia coli Appl. Envron Microbiol., 15, 407-410 (1969).

35) 相楽好治, 澤井 淳, 五十嵐英夫, 橋本 篤, 清水 賢, ストレスにより生じた損傷細菌の評価方法, 化学工学会 第 27 回秋季大会講演要旨集, 0111 (1994).

36）相楽好治, 澤井 淳, 橋本 篤, 清水 賢, 五十嵐英夫： 
ストレスにより生じる損傷細菌についての検討，日本細 菌学雑誌, 49, 203 (1994)

37) Sako, Y., Uchida, A. and Kadota, H.: Isolation and characterization of a magnesium-dependent apurinic sites specific endodeoxyribonuclease from Bacillus subtilis. Agric. Biol. Chem., 44, 567-574 (1980).

38) 澤井 淳, 澤木 崇, 五十嵐英夫, 橋本 篤, 清水 賢: セラミックス $(\mathrm{MgO})$ 紛末スラリーにより引き起こされ る大腸菌の損傷, 化学工学会第 27 回秋季大会講演要旨 集, M122 (1994)

39) Sawai, J., Igarashi, H., Hashimoto, A., Kokugan, T. and Shimizu, M.: Evaluation of growth inhibitory effect of ceramics powder slurry on bacteria. J. Chem. Eng. Japan, 28, 288-293 (1995).

40) Sawai, J., Saito. I., Kanou, F., Igarashi, H., Hashimoto, A., Kokugan, T. and Shimizu, M.: Mutagenicity test of ceramics powders which have growth inhibitory effect on bacteria. J. Chem. Eng. Japan, 28, 352-354 (1995).

41) Sawai, J., Sagara, K., Igarashi, H., Hashimoto, A., Kokugan, T. and Shimizu, M.: Injury of Escherichia coli in physiological phosphate-buffered saline induced by far-infrared irradiation. J. Chem. Eng. Japan, 28, 294-299 (1995).

42) Sinenskey, M.: Homeoviscous adaption a homeostatic process that regulates the viscosity of the membrane lipids in Eschericha coli. Proc. Nat. Acad. Sci. USA, 71, 522-525 (1974).

43) Sogin, S. J. and Ordal, Z. J.: Regeneration of ribosomes and ribosomal ribonucleic acid during repair of thermal injury to Staphylococcus aureus. J. Bacteriol., 94, 1082-1087 (1967)

44) Tomlins, R.I. and Ordal, Z. J.: Precursor ribosomal ribonucleic acid and ribosome accumulation in vivo during the recovery of salmonella typhimurium from thermal injury. J. Bacterial., 107, 134-142 (1971).

45) Tsuchido, T., Katsui, N., Tarauchi, A., Takano, M. and Shibasaki, I.: Destruction of the outer membrane permeability barrier of Escherichia coli by heat treat- ment, Appl. Environ. Microbiol., 50, 298-303 (1985).

46) 土戸哲明. 細菌細胞の熱障害, 化学と生物, 26, 211-213 (1988).

47) Tsuchido, T. and Takano, M.: Sensitization by heat treatment of Escherichia coli K-12 cells to hydrophobic antibacterial components., Antimicrob. Agents Chemother., 32, 1680-1683 (1988).

48) Tsuchido, T., Koike, T. and Takano, M.: A modified assesment of growth inhibition from growth-delay time in a cell population exposed to an environmental stress., J. Ferment. Technol., 67, 132-134 (1989).

49) Tsuchido, T., Aoki, I. and Takano, M.: Interaction of flurorescent dye 1-N-Phenylnaphthylamine with Escherichia coli cells during heat stress and recovery from heat stress. J. Gen. Microbiol., 135, 1941-1947 (1989).

50）土戸哲明; 微生物細胞における高温ストレス. 防菌防徽, 18, 75-87 (1990).

51) 内田有恒，門田 元：加熱による細菌の DNA の損傷と その修復. 微生物の生態 8. 微生物生態研究会編, p. 1532 , 学会出版センター, 東京 (1980).

52) VanBogelen, R. A. and Neidhardt, F. C.: Ribosomes as sensors of heat and cold shock in Escherishia coli. Proc. Nat. Acad. Sci. USA., 87, 5589-5593 (1990).

53) Williams-Hill, D. M. and Gredz, N.: Role of AP endonuclease in DNA breakage and cell inactivation of Escherichia coli Subjected to mild heating. Mut. Res., 107, 13-21 (1983).

54) Woodcock, E. and Grigg, G. C.: Repair of thermally induced DNA breakage in Escherchia coli. Nature New Biol., 237, 76-79 (1972).

55) 柳田友道: 微生物科学 2. p. 475-476, 学会出版セン 夕一, 東京 (1985.)

56) Yura, T., Nagai, H. and Mori, H.: Regulation of the heat-shock response in bacteria. Annu. Rev. Microbiol., 47, 321-350 (1993).

57) Zamenhof, S. and Greer, S.: Heat as an agent producing high frequency of mutations and unstable genes in Escherichia coli. Nature, 182,611-613 (1958). 